\title{
OWNERSHIP STRUCTURE AND INTERNATIONALIZATION: AGENCY PROBLEMS AND DELISTING IN BRAZIL
}

\section{KLEVERSON DÁLITON SILVA MOREIRA}

Universidade Federal de Uberlândia (UFU), Uberlândia - MG, Brazil.

\section{JULIANA RODRIGUES OLIVEIRA}

Universidade Federal de Uberlândia (UFU), Uberlândia - MG, Brazil.

\section{FERNANDA MACIEL PEIXOTO}

Universidade Federal de Uberlândia (UFU), Uberlândia - MG, Brazil.

\author{
VINÍCIUS SILVA PEREIRA \\ Universidade Federal de Uberlândia (UFU), Uberlândia - MG, Brazil.
}

To cite this paper: Pereira, V. S., Peixoto, F. M., Moreira, K. D. S., \& Oliveira, J. R. (2017). Ownership structure and internationalization: agency problems and delisting in Brazil. Revista de Administração Mackenzie, 18(4), 164-189. doi 10.1590/1678-69712017/administracao.v18n4p164-189 


\section{ABSTRACT}

Purpose: This study aimed to analyze determinants related with the delisting of Brazilian companies, through the analysis of the problems of agencies coming from structures of property/control and the internationalization of organizations. Originality/value: The present work seeks to fill the existing gap of more detailed studies related to the delisting of companies in the Brazilian capital market. In addition, it presents a contribution to the literature through the analysis of the relationship between Corporate Governance, Corporate Internationalization and Deslisting from the perspective of Agency Theory.

Design/methodological/approach: Four econometric models based on existing literature were elaborated and then analysis of logit regressions with panel data. For data of all organizations listed in BM\&FBOVESPA in the period between 2006 and 2015, period in which it was found that 205 businesses closed down their capital.

Findings: As a result, it was observed that when considering the year before the delisting, organizations which have greater concentration of property had higher probability of closing their capital, which does not occur when analyzing the control structures. As to the entrance mode into international market, it was noted that there is a negative relationship between entrance mode non-patrimonial and volunteer delisting.

\section{KEYWORDS}

Volunteer Delisting; Agency Problems; Ownership and Control Structure; Internationalization; Entrance mode. 


\section{INTRODUCTION}

A widely studied theme in finance concerns a company's choice to go public and have its shares traded in the stock market, which is considered a stage of corporate growth. According to Bortolon and Silva (2015), this choice provides many benefits, such as increase in the liquidity of securities, expansion of the investor base, and reduction of capital cost and information asymmetry. However, according to Djama, Martinez and Serve (2014), little has been studied about the reverse phenomenon, that is, when a company goes private, also known as delisting.

Bortolon and Silva (2015) pointed out that, in the Brazilian stock market, delistings can happen through two modes regulated by Instructions 287/1998 and 361/2002 of the Brazilian Securities Commission (CVM). The first mode happens involuntarily by means of the extinction of the company, the cancellation of the company's registration in the stock, the evidence of suspension of the company's activities for more than three years, and/or the suspension of a public company's registration for more than one year. The second mode is voluntary, and it involves the Public Offering of Shares (OPA - Oferta Pública de Ações) to cancel the registration or increase the controlling shareholder's equity interest, for example.

According to Djama, Martinez and Serve (2014), from 1996 to 2014, more than 900 companies went private in the United States, and, in the United Kingdom, more than $25 \%$ of the companies listed in the stock exchange went private from 1995 to 2005. In Brazil, Bortolon and Silva (2015) conducted a study about delisting considering the period from 2008 to 2012 . They verified that 100 registrations were canceled, among which 14 were involuntary and 86 were voluntary. Considering the period from 2006 to 2015,205 companies went private in the Brazilian stock market. Among them, 174 went private voluntarily.

The development of the stock market partially depends on the quality of companies' corporate governance. An efficient governance system tends to increase liquidity, trading volume, and stock prices (Rogers, 2006). The determining factors to measure the efficiency of a country's stock market are the volumes of IPOs (Initial Public Offerings) and going private transactions (stock delisting), among others. Therefore, delisting and Corporate Governance (CG) are related subjects, since companies with good corporate governance practices have less probabilities to delist (Santos, 2016). 
According to the Agency Theory, CG mechanisms can be summarized in transparency of published information; ownership and control structure; protection of minority shareholders; compensation to managers; and structure of the board of directors (Correia, 2008). Bortolon and Silva (2015) verified a negative relationship between the CG mechanism "ownership and control structure" and delisting: companies that have better practices related to the ownership and control structure are less likely to go private.

Other relationship presented in the literature regarding CG may be verified in Filatotchev and Wright (2011). They confirmed the influence of internationalization of companies on their agency costs, which emphasizes the existence of different relationships in both equity and non-equity entry modes in the foreign trade. In the process of internationalization through the equity entry mode, the company primarily becomes international through exports, franchises, and by hiring partner companies, that is, internationalization strategies that do not involve investment and maintenance of a structure of its own (equity) in a foreign country. The equity entry mode is the internationalization of a company by means of assets, mergers, and acquisitions, it means, forming its own structure (equity) in the foreign country.

According to Filatotchev and Wright (2011), the forms of internationalization of assets (foreign direct investment, international joint ventures, subsidiaries, global business groups) have more risks, because they establish an infrastructure in a foreign country. This process increases the management complexity and, as a consequence, the agency costs to articulate the interests of shareholders and managers of the head office and the branch abroad. However, a higher risk may provide a higher return, as the company will have broader access to suppliers, finance, and consumer markets, which can affect the delisting of multinational companies that present mainly nonequity internationalization with potentially lower returns.

Thus, this paper aims to verify the relationship among the delisting of Brazilian companies, the mechanisms ownership and control structure, and the internationalization level.

This paper analyzes specific goals: i) the profile of companies that delisted from BM\&FBOVESPA from 2006 to 2017; ii) the factors that lead to going private transactions; and iii) the influence of the mode of entry in international markets in delisting transactions.

To reach the proposed goal, we used the panel data regression method through the elaboration of econometric models with determining factors of delisting mentioned in the literature. Also, we included aspects regarding 
ownership and control structure, internationalization, and entry modes (equity or non-equity).

In Brazil, very few studies have deeply analyzed the delisting of companies in the stock market (Souza, Costa, Almeida, \& Bortolon, 2013). Thus, this paper aims to contribute to the analysis of the relationship among corporate governance, internationalization of companies, and delisting from the Agency Theory point of view.

\section{THEORETICAL FRAMEWORK}

\subsection{INTERNATIONALIZATION AND CORPORATE GOVERNANCE}

The international business theory suggests the Foreign Direct Investment (FDI) is motivated by the desire to explore company-specific assets, such as technological advantages, management skills, and geographic advantages (Dunning, 1977). However, the agency costs arguments of Lee and Kwok (1988) and Burgman (1996) focus on the risks and costs associated with the internationalization of a company. They suggest that multinationals have higher agency costs of debt (due to the increase in the monitoring costs, higher auditing costs, differences in language and legal systems, stock market imperfections, and different asset structures), which implies that multinational corporations should have lower levels of debt in the capital structure.

According to Pereira and Sheng (2012), the entry modes are forms and strategies adopted by multinational companies to expand in the international market by means of exports, acquisitions and mergers abroad, opening of franchises in foreign territories, among others.

Corporate Governance (CG) stood out in the United States in the beginning of the 1980s as a result of a movement of shareholders to increase security in their investments and implement rules against companies' abuses. Large institutional investors realized there was a need for more strict rules for their investments (Burghof \& Schilling, 2003). In short, scandals regarding the stock market in Europe and in the United States boosted studies about CG. Nowadays, CG has become a central topic in the stock market due to its real benefits for shareholders, especially for minority shareholders (Bortolon \& Silva, 2015).

This paper adopts the concept of CG by Shleifer and Vishny (1997), who define CG as a set of mechanisms through which investors ensure 
return on their investment. This concept follows the perspective of Jensen and Meckling's (1976) Agency Theory.

Another widespread governance concept is the one proposed by the Instituto Brasileiro de Governança Corporativa - IBGE (2009) affirms that governance is "a system that rules, monitors and encourages all organizations in the relationships among owners, board of directors, executive board, and control bodies."

Jensen and Meckling (1976) state that transactions in the market are ruled by contracts involving two characters: the principal and the agent. The agent agrees to perform tasks for the principal, this one undertakes to remunerate the agent. However, the agent has his/ her own interests, and they can conflict with the principal's ones. Consequently, the "agency conflict" arises. In order to minimize this conflict, the shareholders of a company incur costs to monitor the managers' activities, resulting in the so-called "agency costs". According to Jensen and Meckling (1976), agency costs consist of three elements: a) the principal's monitoring expenses; b) the agent's expenses to grant contract guarantees; and c) residual loss.

Agency costs are, therefore, essential to understand CG. Among the five corporate governance mechanisms proposed by Correia (2008) ownership and control structure; board of directors; compensation to managers; transparency; and protection of minority shareholders -, we chose to work with the "ownership and control structure" mechanism by analyzing its effect along with the effect of internationalization on the delisting of Brazilian companies.

We noted the risk of deviation of shareholders' resources could explain the separation of ownership and control, for capital suppliers are not directly included in corporate decisions. In most organizations, managers of companies with pulverized ownership structure or majority shareholders in companies with concentrated ownership and control structure do not financially afford the decisions taken. (Berle \& Means, 1932).

\subsection{DELISTING}

Two aspects that researchers have noticed regarding CG are the process of listing (going public in the stock exchange) and voluntary delisting (going private at the initiative of the shareholders), which usually happen in the world capital market. The focus here is the voluntary delisting, which may be understood as the exit of listed companies from the stock exchange. 
Santos (2016) analyzed corporate internationalization and delisting in the Brazilian market. The analysis demonstrated that these processes are directly connected to CG and that there is a relationship between corporate internationalization and delisting, since the benefits created by internationalization increase delisting, especially during crises.

Saito's (2015) study with 119 Brazilian companies from 1999 to 2013 analyzed which are the determining factors for going private. The author found that the reasons for delisting are low profitability, lower payment of dividends associated with higher free cash flow, and lower need to access the debt market. In addition, Saito (2015) verified the economic effects of ownership concentration on delisting through the analysis of total equity interest of controlling shareholders.

However, considering the international market, Bharath and Dittmar (2010) determined that free cash flow can destroy the firm value if the cash available is accessible and used in non-profitable projects, which may lead to the delisting of companies. Companies with financial restrictions have higher chances of remaining public to take advantages of the listing benefits. In addition, Bharath and Dittmar (2010) highlighted those macroeconomic factors may contribute to going private transactions. Furthermore, companies that have higher delisting probability have less analyst coverage, less institutional participations, higher ownership concentration, and more investment funds during the IPO when compared to firms that remain public. Private companies are more illiquid and have a lower business volume, which strengthens the importance of liquidity issues (Bharath; Dittmar, 2010).

Still in the international scenario, Mehran and Peristiani (2010) revealed that companies with a decreasing growth, a decline in the institutional ownership, and a low stock of shares, were more likely to go private. The authors argued that one of the main reasons behind the decisions of companies when abandoning their public listing was the inability to attract a critical mass of financial visibility and investors' interest. They also found support to Jensen's hypothesis on free flow cash: corporate restructuring measures are useful tools in the stock market to mitigate agency problems between insiders and external shareholders. Also, companies with higher non-distributed cash flows are more likely to go private (Mehran \& Peristiani, 2010). 


\section{METHODOLOGY}

In this study, we used a sample of all companies with securities traded in the São Paulo stock exchange, excluding Investment Funds and securities classified in the Finance and Insurance sectors, due to the differences in their structure and accounting standards.

We developed econometric models in which the dependent variable represented the occurrence of delisting. We assigned the value of 1 to the year in which the company went private and 0 to the period in which it remained listed in the stock exchange. This variable is represented by the acronym "DESLIST". Another dependent variable measured voluntary delisting, this variable was named "VOLUNT" and received 1 for companies that delisted voluntarily and 0 for companies that went private involuntarily based on CVM's Instruction 287/1998.

In order to understand the influence of agency costs on the delisting of companies, we selected independent variables to observe this conflict of interests at several levels. The first level is the firm level (considering the ownership and control structure); the second is the scope of internationalization; and, at least, the third level distinguishes multinational companies into two groups: one with equity entry and the other with non-equity entry.

To measure the effects of ownership and control concentration, we used the variables proposed by Claessens, Djankov, Fan and Lang (2002), Silva and Leal (2006), and Marques, Guimarães and Peixoto (2015), measured by the percentage of shares held by the three major shareholders, which received the name PROP. Another variable measured the separation of ownership and control by subtracting the percentage of control of the three major shareholders, subtracted by their participation in the total capital; thus, this variable represents the excess of control in relation to the ownership, named CONT.

In order to analyze the relationship between internationalization and delisting, we considered the degree of internationalization, here presented as an independent variable, called doi (Degree of Internationalization), as proposed by Santos (2016). This author verified a negative relationship between internationalization and delisting, since companies tend to improve their CG practices to obtain the benefits of internationalization, resulting in better market evaluations and in an advantageous permanence in the stock market. 
This paper intends to advance in relation to the results obtained by Bortolon and Silva (2015) and Santos (2016) by adding a variable to verify how the entry mode in international markets affects the delisting of a company. To this end, we considered the inference suggested by Filatotchev and Wright (2011): the mode adopted to internationalize a company affects its agency costs. Those opting for non-equity modes have higher costs, because they include a third party in the company's structure and have difficulties to control owners and managers due to geographical distances. In order to measure this effect, we used a variable proposed by Pereira (2013), which attempts to capture the increase in agency problems for companies delisting, considering their entry mode in international markets.

Finally, we used ownership variables. The first was liquidity (LIQ), representing the value of trade of the securities of a particular company in the stock market; it is calculated by the volume of transactions, as shown in Table 1. We expected to find a negative relationship between the dependent variable and liquidity, as Pour and Lasfer (2013) and Bortolon and Silva (2015) did. The second control variable was the available cash (CAIXA), which, according to Bortolon and Silva (2015), has a positive relationship to delisting. This shows that companies with more cash available are more likely to go private due to the discretion of managers and controlling shareholders. Another variable that may be subject to the discretion of controlling shareholders and managers is the distribution of dividends (DIV), from which a positive sign is also expected. The expected signs from these variables are in accordance with the entrenchment effect reported by Claessens, Djankov, Fan and Lang (2002), since controlling shareholders try to expropriate the minority shareholders to exclusively use the available cash resources and the dividends; in this way, delisting becomes advantageous.

According to Saito and Padilha (2015), companies with lower growth opportunities present a lower need to raise funds and, as consequence, a lower need to use stock market as a source of finance. Thus, we used the variable growth (CRESC), measured by the market-to-book ratio.

Chaplinsky and Ramchand (2012) showed larger companies have sufficient resources to cover listing maintenance costs in the stock exchange in the United States. In Brazil, Bortolon and Silva (2015) indicated that smaller companies receive less attention of the market, which promote going private transactions. Thus, to capture these relationships as a control to the model, the size of the company was measured by the natural logarithm of total assets, and a negative sign was expected. 
Pour and Lasfer (2013) suggest that less indebted companies are more likely to go private due to their leverage potential. For that reason, we used the variable ALAV as proxy of the relationship between the total liabilities and the owner's equity; therefore, we expected a negative relationship.

Chart 1 summarizes all variables included in the econometric model elaborated in this study and shows the calculation formula for each variable and previous study that has used them.

\section{(Chart 1)}

\section{CLASSIFICATION OF VARIABLES}

Chart 1 shows the study variables and their types, abbreviations, measurement forms, and data source, as well as the authors who have used these variables in former studies.

\begin{tabular}{|c|c|c|c|c|c|}
\hline Variable & $\begin{array}{l}\text { Variable } \\
\text { type }^{a}\end{array}$ & Abbreviation & Measurement & Source & Authors $^{\mathrm{b}}$ \\
\hline Delisting & DV & DESLIST & $\begin{array}{l}\text { Control dummies: } \\
1 \text { for companies that went } \\
\text { private } \\
0 \text { for other companies }\end{array}$ & $\begin{array}{l}\text { CVM and } \\
\text { BM\&FBOVESPA }\end{array}$ & $\begin{array}{l}(1),(2), \\
\text { and (4) }\end{array}$ \\
\hline
\end{tabular}

\begin{tabular}{llll}
\hline & Control dummies: & CVMand \\
Voluntary delisting & DV $\quad$ VOLUNT & $\begin{array}{l}1 \text { for voluntary delisting } 0 \text { for } \\
\text { involuntary delisting }\end{array}$ & BM\&FBOVESPA
\end{tabular}

\begin{tabular}{lllll}
\hline $\begin{array}{l}\text { Ownership } \\
\text { concentration }\end{array}$ & IVI & PROP & $\begin{array}{l}\text { \% of common and preferred } \\
\text { shares held by the three } \\
\text { major shareholders }\end{array}$ & Economatica \\
\hline $\begin{array}{l}\text { Control } \\
\text { concentration }\end{array}$ & IVI & CONT & $\% 3 C O N T$ - \%3PROP & Economatica
\end{tabular}

\begin{tabular}{|c|c|c|c|c|c|}
\hline $\begin{array}{l}\text { Degree of } \\
\text { Internationalization }\end{array}$ & IVI & DOI & $\begin{array}{l}\text { Arithmetic average of } \\
\text { (foreign assets/assets), } \\
\text { (sales abroad/sales) } \\
\text { and (employees abroad/ } \\
\text { employees) }\end{array}$ & $\begin{array}{l}\text { FDC ranking } \\
\text { (Fundação Dom } \\
\text { Cabral Business } \\
\text { School) }\end{array}$ & $\begin{array}{c}(4) \\
\text { and (5) }\end{array}$ \\
\hline
\end{tabular}

\begin{tabular}{|c|c|c|c|c|c|}
\hline $\begin{array}{l}\text { Types of entry } \\
\text { modes }\end{array}$ & IVI & EMODT & $\begin{array}{l}\text { Control dummies: } \\
1 \text { equity entry mode } \\
2 \text { non-equity entry mode } \\
0 \text { domestic companies }\end{array}$ & $\begin{array}{l}\text { FDC ranking } \\
\text { (Fundação Dom } \\
\text { Cabral Business } \\
\text { School) }\end{array}$ & $\begin{array}{l}\text { (5) } \\
\text { and (6) }\end{array}$ \\
\hline
\end{tabular}

(continue) 


\section{(Chart 1) \\ CLASSIFICATION OF VARIABLES}

Chart 1 shows the study variables and their types, abbreviations, measurement forms, and data source, as well as the authors who have used these variables in former studies.

\begin{tabular}{|c|c|c|c|c|c|}
\hline Variable & $\begin{array}{l}\text { Variable } \\
\text { type }^{a}\end{array}$ & Abbreviation & Measurement & Source & Authors $^{\mathrm{b}}$ \\
\hline Liquidity & ICV & LIQ & (c) $100 * \frac{P}{P} * \sqrt{\frac{\Pi}{N} * \frac{V}{V}}$ & Economatica & $\begin{array}{l}(1) \\
\text { and (2) }\end{array}$ \\
\hline Available cash & ICV & CAIXA & $\frac{\text { EBITDA }}{\text { Total Income }}$ & Economatica & (1) \\
\hline $\begin{array}{l}\text { Payment of } \\
\text { dividends }\end{array}$ & ICV & DIV & $\begin{array}{l}\text { Dividend yeld x Delisting } \\
\text { price }\end{array}$ & Economatica & (1) \\
\hline $\begin{array}{l}\text { Growth } \\
\text { opportunities }\end{array}$ & ICV & CRESC & $\frac{\text { Market Value }}{\text { Owner's Equity }}$ & Economatica & $\begin{array}{l}(1),(7) \\
\text { and (8) }\end{array}$ \\
\hline Company size & ICV & TAM & Natural Logarithm of Assets & Economatica & $\begin{array}{l}(1) \\
\text { and (8) }\end{array}$ \\
\hline Leverage & ICV & ALAV & $\frac{\text { Total Liabilities }}{\text { Owner's Equity }}$ & Economatica & (1) \\
\hline
\end{tabular}

(a): DV: Dependent variable; IVI: Independent variable of interest; ICV: Independent control variable. (b): (1) Bortolon and Silva (2015); (2) Pour and Lasfer (2013); (3) Claessens, Djankov, Fan and Lang (2002);

(4) Santos (2016); (5) Pereira (2013); (6) Filatotchev and Wright (2011); (7) Saito and Padilha (2015);

(8) Chaplinsky and Ramchand (2012). (c): $p$ = number of days with at least one share traded within the chosen period; $P$ = total number of days in the chosen period; $n=$ number of trades with a share within the chosen period; $\mathrm{N}=$ number of trades with all shares within the chosen period; $\mathrm{v}$ = cash volume with $\mathrm{a}$ share within the chosen period; $V$ = cash volume with all shares within the chosen period.

Source: Elaborated by the authors.

Based on the variables previously demonstrated, we elaborated four econometric models, shown in equations 1 and 2, where $\varepsilon i$ represents the error term.

DESLIST $_{i t}=\alpha+\beta_{1}$ PROP $_{i t}+\beta_{2}$ CONT $_{i t}+\beta_{3}$ LIQ $_{i t}+\beta_{4}$ CAIXA $_{i t}+$ $\beta_{5}$ DIV $_{\text {it }}+\beta_{6}$ CRESC $_{i t}+\beta_{7}$ TAM $_{\text {it }}+\beta_{8}$ ALAV $_{\text {it }}+\varepsilon i$ 
$V_{\text {OLUNT }}=\alpha+\beta_{1}$ PROP $_{i t}+\beta_{2}$ CONT $_{i t}+\beta_{3}$ LIQ $_{i t}+\beta_{4}$ CAIXA $_{i t}+$ $\beta_{5}$ DIV $_{\text {it }}+\beta_{6}$ CRESC $_{\text {it }}+\beta_{7}$ TAM $_{\text {it }}+\beta_{8}$ ALAV $_{\text {it }}+\varepsilon i$

DESLIST $_{i t}=\alpha+\beta_{1}$ DOI $_{i t}+\beta_{2}$ EMODT $_{\text {it }}+\beta_{3}$ LIQ $_{\mathrm{it}}+\beta_{4}$ CAIXA $_{\mathrm{it}}+$ $\beta_{5}$ DIV $_{i t}+\beta_{6}$ CRESC $_{i t}+\beta_{7}$ TAM $_{i t}+\beta_{8}$ ALAV $_{\text {it }}+\varepsilon i$

$V_{\text {OLUNT }}=\alpha+\beta_{1} \mathrm{DOI}_{\mathrm{it}}+\beta_{2} \mathrm{EMODT}_{\mathrm{it}}+\beta_{3} \mathrm{LIQ}_{\mathrm{it}}+\beta_{4} \mathrm{CAIXA}_{\mathrm{it}}+$ $\beta_{5} \mathrm{DIV}_{\mathrm{it}}+\beta_{6} \mathrm{CRESC}_{\mathrm{it}}+\beta_{7} \mathrm{TAM}_{\mathrm{it}}+\beta_{8} \mathrm{ALAV}_{\mathrm{it}}+\varepsilon i$

\subsection{STUDY HYPOTHESES}

Considering the variables and relationships described in the previous topic, we raised the following hypotheses:

Hypothesis 1a: there is a positive relationship between ownership and control concentration and delisting.

This hypothesis is supported by the evidence presented in Bortolon and Silva (2015). They suggested that companies with a higher CG quality in relation to ownership and control structure have lower probabilities of delisting, since the stock exchange offers these companies several benefits, such as brand value enhancement, easier access to finance, low-cost fundraising, expansion to international markets etc. Therefore, to accept this hypothesis, we expect the results of the regression model to present positive signs for the coefficients of the variables PROP and/or CONT.

Hypothesis 1b: companies with higher ownership and control concentration have a higher probability of voluntarily going private.

According to Bortolon and Silva (2015), involuntary delisting mainly happens because of the deterioration of a company's results and does not involve only the company's decision, but also CVM and even legal proceedings. In addition, the ownership and control structure can influence less directly the cancellation of the company's registration in the stock exchange. Hence, we expect the ownership and/or control concentration will raise the probability of companies to go private voluntarily.

Hypothesis 2a: there is a positive relationship between the non-equity entry mode and delisting.

According toFilatotchevandWright (2011), companies that internationalize through foreign direct investment, acquisition of subsidiaries, and joint ventures are likely to have bigger agency problems due to the decentralization of management activities. Santos (2010) and Saito and Padilha (2015) added that the biggest agency problems are related to company delisting, since this 
action increases the management of results and creates favorable conditions for the purchase of companies for a price below the value considered fair.

Hypothesis $2 \mathrm{~b}$ : there is a negative relationship between the non-equity entry mode and voluntary delisting.

The last hypothesis aligns with the evidence verified by Santos (2016), whose results showed that the higher the degree of internationalization of a company, the lower its probability of delisting. Specially about the non-equity entry mode, Pereira (2013) states that companies which internationalized through a non-equity mode reduce their risks and, as a consequence, their agency costs, which increase their fundraising potential. Saito and Padilha (2015) presented that companies with lower financial restrictions show a lower probability of going private. Therefore, considering that companies with non-equity entry mode show lower agency problems and lower financial restrictions, they tend to have lower probabilities of voluntarily delisting.

Chart 2 shows a summary of the expected signs for the coefficients of the independent variables of interest and independent control variables aligned with the literature and the hypotheses of this study.

\section{(Chart 2)}

EXPECTED SIGNS OF THE COEFFICIENTS OF VARIABLES

\begin{tabular}{lcc}
\hline Variable & Abbreviation & Expected signs \\
\hline Ownership concentration & PROP & + \\
\hline Control concentration & CONT & + \\
\hline Degree of internationalization & DOI & + \\
\hline Types of entry mode & Equity & - \\
\cline { 2 - 3 } & Non-equity & + \\
\hline Liquidity & LIQ & + \\
\hline Available cash & CAIXA & - \\
\hline Payment of dividends & DIV & - \\
\hline Growth opportunities & CRESC & - \\
\hline Company size & TAM & + \\
\hline Leverage & ALAV & + \\
\hline
\end{tabular}

Source: Elaborated by the authors. 


\section{ANALYSIS OF RESULTS}

We will present in this session the results of the data analysis. The first part defines the profile of the companies that delisted in the stock exchange of São Paulo from 2006 to 2015.

During this period, 205 companies delisted: 174 companies ( $85 \%$ of the total) voluntarily canceled their registration; the remaining 31 companies did not meet the requirements to have their shares traded at BM\&FBOVESPA for lack of registration update or extrajudicial liquidation. Table 1 shows these data.

\section{(Table 1)}

DELISTING OF BRAZILIAN COMPANIES

\begin{tabular}{lccc}
\hline & \multicolumn{2}{c}{ Delisting } \\
\hline Year & General & Voluntary & Involuntary \\
\hline 2006 & 25 & 22 & 3 \\
\hline 2007 & 16 & 16 & 0 \\
\hline 2008 & 24 & 22 & 2 \\
\hline 2009 & 20 & 16 & 4 \\
\hline 2010 & 21 & 19 & 2 \\
\hline 2011 & 28 & 15 & 13 \\
\hline 2012 & 27 & 23 & 4 \\
\hline 2013 & 14 & 11 & 0 \\
\hline 2014 & 15 & 15 & 0 \\
\hline 2015 & 15 & 15 & $\mathbf{3 1}$ \\
\hline T0TAL & $\mathbf{2 0 5}$ & $\mathbf{1 7 4}$ & \\
\hline
\end{tabular}

Source: Elaborated by the authors.

29 companies were excluded from the sample of delisted companies because they were classified in the financial, insurance and investment funds sectors, and others 29 companies were excluded for not having the 
information needed to calculate the study variables; therefore, the final sample had 147 delisted companies.

In the descriptive statistics analysis, we observed first a pattern in the study variables regarding those companies that voluntarily delisted in comparison to the others to identify which variables determined the intentional cancellation of registration in the stock exchange. These data are available in Table 2.

On average, the companies that voluntarily delisted showed higher ownership concentration $(87.24 \%)$ in relation to those that did not delist or involuntarily delisted (66.95\%). Regarding the excess of control in relation to ownership, companies that voluntarily delisted had lower divergence between the ownership and control levels, showing high concentration and lower protection of the minority shareholders. Consequently, the probability of expropriation increased according to Claessens, Djankov, Fan and Lang (2002), specially in countries with low legal protection, like Brazil.

\section{(Table 2)}

COMPARISON OF DESCRIPTIVE STATISTICS REGARDING VOLUNTARY DELISTING

\begin{tabular}{lcccccccc}
\hline & \multicolumn{3}{c}{ Did not delist } & \multicolumn{5}{c}{ Voluntarily delisted } \\
Variable & $\begin{array}{c}\text { No. of } \\
\text { observations }\end{array}$ & Average & Minimum & Maximum & $\begin{array}{c}\text { No. of } \\
\text { observations }\end{array}$ & Average & Minimum & Maximum \\
\hline PROP & 3326 & 66.95 & 0.14 & 100.00 & 68 & 87.24 & 30.44 & 100.00 \\
\hline CONT & 3326 & 8.55 & -64.60 & 63.14 & 68 & 5.02 & -2.86 & 38.85 \\
\hline DOI & 6463 & 0.01 & 0.00 & 0.62 & 128 & 0.002 & 0.00 & 0.25 \\
\hline LIQ & 6492 & 0.10 & 0.00 & 13.86 & 128 & 0.04 & 0.00 & 0.74 \\
\hline CAIXA & 3141 & -1.91 & -1759.45 & 1193.31 & 10 & -50.73 & -507.75 & 0.50 \\
\hline DIV & 2631 & 117.19 & 0.00 & 32382.48 & 7 & 51.08 & 0.00 & 102.99 \\
\hline CRESC & 2811 & 13.57 & -0.51 & 29688.19 & 7 & 1.66 & 0.57 & 4.05 \\
\hline TAM & 3891 & 20.61 & 2.65 & 27.68 & 10 & 22.05 & 12.33 & 25.17 \\
\hline ALAV & 3892 & 238.42 & -749.18 & 918778.00 & 10 & 1.71 & -1.00 & 6.90 \\
\hline
\end{tabular}

Source: Elaborated by the authors. 
By analyzing the degree of internationalization, we noted that Brazilian companies usually have low levels of internationalization; those with a higher degree of internationalization show a lower delisting probability. The delisted companies observed had only $0.2 \%$ of international trades out of the total, while companies that had not delisted presented $1 \%$ of international trades on average. Considering the control variables, companies that voluntarily delisted showed less available cash and higher leverage than companies which had their registration canceled. This fact may indicate that companies voluntarily delist trying to increase their resource availability. According to Saito and Padilha (2015), these companies have restricted access to debt financing sources and cannot obtain more resources by issuing shares, which makes delisting interesting. In this way, managers seem to believe that the company will have more resources available in the future and try to expropriate shareholders through delisting, even before it is settled.

Table 3 shows the descriptive statistics of the study variables according to the entry mode of internationalization of the companies in the sample.

\section{(Table 3)}

COMPARISON OF THE STUDY VARIABLES

REGARDING INTERNATIONALIZATION

\begin{tabular}{lllllll}
\hline & \multicolumn{2}{c}{ Domestic } & \multicolumn{2}{c}{ Equity } & \multicolumn{2}{c}{ Non-equity } \\
\hline Variable & $\begin{array}{c}\text { No. of } \\
\text { observations }\end{array}$ & Average & $\begin{array}{c}\text { No. of } \\
\text { observations }\end{array}$ & Average & $\begin{array}{c}\text { No. of } \\
\text { observations }\end{array}$ & Average \\
\hline PROP & 2985 & 68.73 & 63 & 46.77 & 336 & 59.37 \\
\hline CONT & 2985 & 7.86 & 63 & 18.68 & 336 & 12.18 \\
\hline DOI & 6118 & 0.00 & 69 & 0.22 & 403 & 0.05 \\
\hline LIQ & 6136 & 0.07 & 70 & 1.27 & 403 & 0.33 \\
\hline CAIXA & 2715 & -2.43 & 67 & 0.18 & 359 & 0.18 \\
\hline DIV & 2274 & 123.97 & 60 & 161.56 & 295 & 55.60 \\
\hline CRESC & 2411 & 15.59 & 65 & 1.21 & 333 & 1.43 \\
\hline TAM & 3451 & 20.43 & 67 & 23.25 & 373 & 21.82 \\
\hline ALAV & 3452 & 268.71 & 67 & -8.80 & 373 & 2.47 \\
\hline
\end{tabular}

Source: Elaborated by the authors. 
Companies that did not internationalize (domestic companies) have higher ownership concentration; however, they present less excess of control regarding ownership. These data are consistent with the profile of companies that delisted, because they show a negative relationship between internationalization and delisting, as verified by Santos (2016).

As to the degree of internationalization, companies that entered through the equity mode had a higher volume of international transactions than those in the non-equity entry mode, which is not corroborated by the theory. This last entry mode requires the purchase of assets and employee maintenance, which increases resource application beyond borders. According to Filatotchev and Wright (2011), companies that internationalized through non-equity modes require lower investments; however, these modes contribute to raise agency costs, as the head office faces difficulties in monitoring activities performed by third parties in other countries.

Table 4 also shows that internationalized companies are larger and have higher liquidity levels in the stock market and more cash available, as opposed to fewer growth and leverage opportunities.

After the preliminary statistical analysis of the study variables, we verified their adequacy to the panel data regression method. The dependent variable in this study is binary. For that reason, as opposed to multiple linear regression models, the regression model with binary variables does not need to meet the assumptions of homoscedasticity, linearity and normality of residues to eliminate problems of multicollinearity (Kleinbaum, Klein \& Pryor, 2010).

First we performed the correlation analysis using the Pearson coefficient, which showed the existence of multicollinearity problems in the Degree of Internationalization (DOI). It determined the non-inclusion of this variable in the following analyses. Then we performed the Variance Inflation Factor (VIF) test to identify more multicollinearity cases, which did not indicate any problems.

In the next step, we conducted a test to verify which regression model was most suitable to the data (logit or probit), and we verified that the panel data logistic regression model presented better results; therefore, we used the mentioned test in the next steps. We conducted the Hausman test with all models applied. It showed that logistic regression should be carried out with random effects, which was more suitable to the data.

In summary, we analyzed the models proposed in the methodology section to identify the relationship between the delisting of Brazilian companies and the agency costs arising from the ownership, control and internationalization structure. Table 4 shows these results. 


\section{(Table 4)}

PANEL DATA REGRESSION RESULTS

\begin{tabular}{|c|c|c|c|c|}
\hline & Model 1 & Model 2 & Model 3 & Model 4 \\
\hline Factors to be observed & \multicolumn{2}{|c|}{ Ownership and control structure } & \multicolumn{2}{|c|}{ Entry modes } \\
\hline Dependent variable & DESLIST & VOLUNT & DESLIST & VOLUNT \\
\hline Independent variables & \multicolumn{4}{|c|}{ Probability of occurrence } \\
\hline \multirow{2}{*}{ PROP } & 1.0121 & 1.0083 & & \\
\hline & $(0.60)$ & $(0.36)$ & & \\
\hline \multirow{2}{*}{ CONT } & 1.0204 & 1.0093 & & \\
\hline & $(0.76)$ & $(0.29)$ & & \\
\hline \multirow{2}{*}{ LIQ } & $1.03 e+17$ & $3.31 e+83$ & $6.14 \mathrm{e}+11$ & $2.11 e^{+81}$ \\
\hline & $(0.52)$ & $(0.81)$ & $(0.39)$ & $(0.81)$ \\
\hline \multirow{2}{*}{ CAIXA } & 0.7377 & .0973 & 0.0780 & 0.1107 \\
\hline & $(-1.30)$ & $(-0.99)$ & $(-1.29)$ & $(-0.98)$ \\
\hline \multirow{2}{*}{ DIV } & 0.9922 & 0.9923 & 0.9914 & 0.9908 \\
\hline & $(-1.05)$ & $(-0.90)$ & $(-1.08)$ & $(-0.98)$ \\
\hline \multirow{2}{*}{ CRESC } & $3.3882^{\star \star}$ & $3.7450^{\star \star}$ & $3.5419^{\star \star}$ & $4.1954^{\star \star}$ \\
\hline & $(2.32)$ & $(2.17)$ & (2.38) & $(2.31)$ \\
\hline \multirow{2}{*}{ TAM } & $2.1470 * \star$ & 2.0138 & $2.2633^{\star \star}$ & 2.1278 \\
\hline & $(2.01)$ & $(1.5)$ & $(-2.15)$ & $(1.62)$ \\
\hline \multirow{2}{*}{ ALAV } & 0.9657 & 1.1564 & 0.9563 & 0.1542 \\
\hline & $(-0.14)$ & $(0.53)$ & $(-0.18)$ & $(0.53)$ \\
\hline \multirow{2}{*}{ Equity entry mode } & & & 2.9527 & 3.6936 \\
\hline & & & $(0.94)$ & $(1.09)$ \\
\hline \multirow{2}{*}{ Non-equity entry mode } & & & 0.7226 & 5.87e-11 \\
\hline & & & $(-0.30)$ & $(-0.00)$ \\
\hline
\end{tabular}

(continue) 


\section{(Table 4)}

PANEL DATA REGRESSION RESULTS

\begin{tabular}{l|c|c|c|c}
\hline & Model 1 & Model 2 & Model 3 & Model 4 \\
\hline Factors to be observed & Ownership and control structure & \multicolumn{2}{c}{ Entry modes } \\
\hline Dependent variable & DESLIST & VOLUNT & DESLIST & VOLUNT \\
\hline Independent variables & \multicolumn{4}{|c}{ Probability of occurrence } \\
\hline \multirow{2}{*}{ Constant } & $1.62 e-11^{\star \star \star}$ & $3.14 e-11^{\star \star}$ & $1.31 e-11^{\star \star \star}$ & $1.43 e-12^{\star \star \star}$ \\
\cline { 2 - 5 } & $(-3.02)$ & $(-2.46)$ & $(-3.00)$ & $(-2.51)$ \\
\hline No. of observations & 2153 & 2153 & 2327 & 2327 \\
\hline
\end{tabular}

T statistics in parenthesis

Levels of significance: ${ }^{\star} p<0.1,{ }^{\star \star} p<0.05,{ }^{* \star *} p<0.01$

\section{Source: Elaborated by the authors.}

Regarding delisting in general, the results of Models 1 and 3 in Table 4 show there is not a statistically significant relationship between ownership and control structures, internationalization entry modes, and cancellation of registration of Brazilian companies in the stock exchange. However, these models show a positive, statistically significant relationship between growth opportunities, size and the delisting probability. Saito and Padilha (2015) verified that the levels of investment fall by nearly half in the delisting year due the absence of growth opportunities, since the company is planning to go private in this period. We verified a positive relationship between size and delisting, which diverged from the analyzed literature and the expected results. Pour and Lasfer (2013) and Santos (2016) explained this relationship: larger companies have less financial restrictions because they are more observed by the market and show less information asymmetry; as they do not lose these benefits in case of delisting, this transaction becomes attractive as a mean of cutting registration maintenance costs.

When we verified a company's intention to cancel its registration through Models 2 and 4, we had similar results to those found in Models 1 and 3; yet we could not state if there is a relationship between company size and voluntary delisting.

However, a company's decision to delist does not happen immediately. This decision is based on past indicators, because most cancellations of registration take time to fulfill all requirements, such as making an OPA and 
waiting for the financial settlement. In this way, we analyzed the relationship between the delisting of companies and their indicators in the previous year, like Saito and Padilha (2015), to capture this relationship in the decisionmaking moment of cancelling the registration in the stock exchange, as presented in Table 5.

\section{(Table 5)}

\section{REGRESSION RESULTS WITH FUTURE DELISTING}

\begin{tabular}{|c|c|c|c|c|}
\hline & Model 1 & Model 2 & Model 3 & Model 4 \\
\hline Factors to be observed & \multicolumn{2}{|c|}{ Ownership and control structure } & \multicolumn{2}{|c|}{ Entry modes } \\
\hline Dependent variable & DESLIST & VOLUNT & DESLIST & VOLUNT \\
\hline Independent variables & \multicolumn{4}{|c|}{ Probability of occurrence } \\
\hline \multirow{2}{*}{ PROP } & $1.0226^{\star}$ & $1.0285^{\star \star}$ & & \\
\hline & (1.93) & $(2.10)$ & & \\
\hline \multirow{2}{*}{ CONT } & 1.0156 & 1.0183 & & \\
\hline & $(0.98)$ & $(1.00)$ & & \\
\hline \multirow{2}{*}{ LIQ } & 5.90e-07 & 0.0415 & $1.44 \mathrm{e}-12$ & 2.33e-10 \\
\hline & $(-0.49)$ & $(-0.10)$ & $(-1.12)$ & $(-0.84)$ \\
\hline \multirow{2}{*}{ CAIXA } & 0.3825 & 0.5302 & 0.5110 & 0.6805 \\
\hline & $(-1.01)$ & $(-0.61)$ & $(-0.79)$ & $(-0.42)$ \\
\hline \multirow{2}{*}{ DIV } & 0.9989 & 0.9999 & 1.0003 & 1.0011 \\
\hline & $(-0.37)$ & $(-0.02)$ & $(0.11)$ & $(0.41)$ \\
\hline \multirow{2}{*}{ CRESC } & 1.3296 & 1.1999 & 1.3165 & 1.2206 \\
\hline & $(0.99)$ & $(0.56)$ & $(1.06)$ & $(0.7)$ \\
\hline \multirow{2}{*}{ TAM } & 1.2830 & 1.2553 & $1.2960^{*}$ & 1.2610 \\
\hline & (1.49) & $(1.22)$ & $(1.74)$ & $(1.43)$ \\
\hline \multirow{2}{*}{ ALAV } & 0.9067 & 0.9416 & 0.8436 & 0.8670 \\
\hline & $(-0.74)$ & $(-0.42)$ & $(-1.35)$ & $(-1.06)$ \\
\hline
\end{tabular}




\section{(Table 5) \\ REGRESSION RESULTS WITH FUTURE DELISTING}

\begin{tabular}{|c|c|c|c|c|}
\hline & Model 1 & Model 2 & Model 3 & Model 4 \\
\hline Factors to be observed & \multicolumn{2}{|c|}{ Ownership and control structure } & \multicolumn{2}{|c|}{ Entry modes } \\
\hline Dependent variable & DESLIST & VOLUNT & DESLIST & VOLUNT \\
\hline Independent variables & \multicolumn{4}{|c|}{ Probability of occurrence } \\
\hline \multirow{2}{*}{ Equity entry mode } & & & 0.4544 & 0.4166 \\
\hline & & & $(-0.68)$ & $(-0.72)$ \\
\hline \multirow{2}{*}{ Non-equity entry mode } & & & 0.3745 & $0.2660^{*}$ \\
\hline & & & $(-1.61)$ & $(-1.86)$ \\
\hline \multirow{2}{*}{ Constant } & $0.0001^{\star \star \star}$ & $8.53 e-06^{\star \star \star}$ & $0.0001^{\star \star \star}$ & $0.0001^{\star \star \star}$ \\
\hline & $(-2.84)$ & $(-2.66)$ & $(-2.95)$ & $(-2.64)$ \\
\hline No. of observations & 1921 & 1921 & 2091 & 2091 \\
\hline
\end{tabular}

T statistics in parenthesis

Levels of significance: ${ }^{*} p<0.1,{ }^{\star *} p<0.05,{ }^{* \star *} p<0.01$

Source: Elaborated by the authors.

Table 5 shows that, for each percentage point added to the concentration of ownership of the three major shareholders of a company, the probability of delisting in general increases in 1.0226, and the chance of voluntary delisting increases in 1.0285. These results are consistent with the hypothesis $1 \mathrm{~b}$ for the variable PROP. Therefore, according to Bortolon and Silva (2015), companies with a better quality of corporate governance in relation to the ownership structure are less likely to delist.

Saito and Padilha (2015) complement the aforementioned idea affirming the Brazilian stock market is still little developed. Ownership is concentrated in most companies; they often choose to cancel their registration to reorganize the company, and some believe that benefits can no longer outweigh the costs of keeping the company listed, so that the owner can have the resources under his/her exclusive control.

When considering internationalization by entry modes, we observed a negative, statistically significant relationship at the level of $10 \%$, according to the hypothesis $2 \mathrm{~b}$. We considered the non-equity entry mode taking 
only the amount of exports performed by companies. For that reason, we assumed agency problems did not increase, because companied did not have to establish themselves in another country and depend on thirdparty operation of their activities. In this way, a company that chooses the non-equity internationalization has only $27 \%$ chance of voluntarily delisting when compared to domestic companies. It also means that noninternationalized companies have $73 \%$ more chances to voluntarily delist, which is in accordance with Santos's study (2016): there is a negative relationship between internationalization and delisting. However, this author identified only the relationship between internationalization and delisting, while our study verified that this relationship exists only for companies internationalized through the non-equity mode.

Pereira (2013) explains this difference of entry modes. He points out that companies internationalized through a non-equity mode have less risks and, consequently, lower financial constraints, which also reduces their probability of delisting. According to Saito and Padilha (2015), the restriction on raising external resources is a determining factor for companies that need new funding options to go private.

Based on this new form of analysis, we verified that only the size of a company presents a positive relationship with delisting. We did not find any significance for the other indicators and developed an analysis similar to the one in Table 5. In this matter, Santos (2016) affirms that larger companies do not benefit from the reduction of financial constraint by staying listed.

\section{FINAL REMARKS}

This study identified determining factors related to the delisting of Brazilian companies through the analysis of agency problems resulting from ownership and control structures and internationalization.

We elaborated four econometric models based on the literature; then, we carried out a logit panel data regression analysis with the data of all companies that traded their securities at BM\&FBOVESPA from 2006 to 2015. In this period, 205 companies went private.

As a result of these analyses, we presented a positive, statistically significant relationship between the control variables growth and company size. According to Saito and Padilha (2015) and Santos (2016), companies that invest less do not expect high returns, and the large ones do not take advantage of the benefit to increase access to funding. By opting for delisting, 
they do not have to bear the costs of keeping their registration. Regarding the independent variables of interest, we first observed that companies with high ownership concentration in the year before delisting are more likely to go private. Bortolon and Silva (2015) also showed a relationship between the ownership and control structure and delisting; however, our results revealed that this relationship only includes ownership concentration, without any significant relation to control structures. Concentrated structures have high agency costs, which makes the cancellation of registration viable. Then, the owner can enjoy the benefits of his/her company exclusively, as pointed out by Saito (2015) and the hypotheses $1 \mathrm{a}$ and $1 \mathrm{~b}$ of this study.

Regarding entry modes in the international market, we identified a negative, statistically significant relationship between the non-equity entry mode and voluntary delisting. This result contradicts the evidence found in Filatotchev and Wright (2011): companies that do not physically settle beyond national borders increase their agency costs, which discards the study hypothesis 2a. However, this result is explained in Pereira (2013). Companies internationalized through non-equity entry modes present lower financial risks, which consequently reduces their financial constraint. According to Saito and Padilha (2015), this is determinant to delisting and confirms hypothesis $2 \mathrm{~b}$.

Finally, this research has limitations, since we could not analyze the existing relationship among all corporate governance mechanisms to contribute to reduce agency problems and going private transactions. Besides, a deeper analysis of the effects of multinationals' financial restriction on the cancellation of stock market registration is needed. It can disclosure new determinants of the delisting of companies, which may be presented in future studies.

\section{REFERENCES}

Berle, A. A., \& Means, G. C. (1932). The modern corporation and private property. New York, NY: MacMillan.

Bharath, S. T., \& Dittmar, A. K. (2010). Why do firms use private equity to opt out of public markets?, Review of Financial Studies, 23(5), 1771-1818. doi $10.1093 / \mathrm{rfs} / \mathrm{hhq016.}$

Bortolon, P. M., \& Silva, A., Jr. (2015). Deslistagem de Companhias Brasileiras Listadas na Bolsa de Valores: Evidências Empíricas sobre a Governança Corporativa. Brazilian Business Review, 12 (Ed.especial), 97-124. doi 10.15728/bbrconf.2015.5. 
Burghof, H. P., \& Schilling, D. (2003). Going private as corporate governance transaction. Betriebswirtschaftliche Forschung und Praxis, 55, 117-136.

Burgman, T. A. (1996). An empirical examination of multinational capital structure. Journal of International Business Studies, 27(3), 553-570. doi 10.1057/ palgrave.jibs.8490143.

Chaplinsky S., \& Ramchand, L. (2012). What drives delistings of foreign firms from U.S. Exchanges? Journal of International Financial Markets, Institutions \& Money, 22(5), 1126-1148. doi 10.1016/j.intfin.2012.06.003.

Claessens, S., Djankov, S., Fan, J. P., \& Lang, L. H. (2002). Disentangling the incentive and entrenchment effects of large shareholdings. The Journal of Finance, 57(6), 2741-2771. doi 10.1111/1540-6261.00511.

Djama, C., Martinez, I., \& Serve, S. (2012). What do we know about delistings? A survey of the literature. Comptabilités et innovation, cd-rom.

Dunning, J. H. (1977). Trade, location of economic activity and the MNE: a search for an eclectic approach. In Ohlin, B., Hesselborn, P. O., \& Wijkman, P. M., (Eds.). The International Allocation of Economic Activity (pp. 395-418). Macmillan London: Palgrave Macmillan.

Filatotchev, I., \& Wright, M. (2011). Agency perspectives on corporate governance of multinational enterprises. Journal of Management Studies, 48(2), 471-486. doi 10.1111/j.1467-6486.2010.00921.x.

Instituto Brasileiro de Governança Corporativa. (2009). Código de Melhores Práticas de Governança Corporativa (4th ed.). São Paulo, SP: IBGC.

Jensen, M. C., \& Meckling, W. (1976). Theory of the firm: managerial behavior, agency costs and capital structure. Journal of Financial Economics, 3(4), 305-360. doi 10.1016/0304-405X(76)90026-X.

Lee, K., \& Chuck C. Y. K. (1988). Multinational corporations vs. domestic corporations: International environmental factors and determinants of capital structure. Journal of International Business Studies, 19(2), 195-217. doi 10.1057/palgrave.jibs.8490381.

Kleinbaum, D. G., Klein, M., \& Pryor, E. R. (2010) Logistic regression: a selflearning text (3rd ed.). New York, NY: Springer.

Marques, T. D. Á., Guimarães, T. M., \& Peixoto, F. M. (2015). A Concentração Acionária No Brasil: Análise Dos Impactos No Desempenho, Valor E Risco Das Empresas. Revista de Administração Mackenzie, 16(4), 100-133. doi 10.1590/1678-69712015/administracao.v16n4p100-133.

Mehran, H.; \& Peristiani, S. (2010).Financial visibility and the decision to go private. Review of Financial Studies, 23(2), 519-547. doi 10.1093/rfs/hhp044. 
Pereira, V. (2013). Ensaios sobre os Efeitos da Internacionalização na Estrutura de Capital e Estrutura de Propriedade de Multinacionais Latino-Americanas (2013). Tese de doutorado, Escola de Administração de Empresas de São Paulo, Fundação Getúlio Vargas, São Paulo, SP, Brasil.

Pereira, V. S., \& Sheng, H. H. (2012). Os efeitos dos modos de entrada sobre o endividamento das multinacionais. In: $12^{\circ}$ Encontro Brasileiro de Finanças, São Paulo. Anais São Paulo: FEA/USP.

Pour, E. K., \& Lasfer, M. (2013). Why do companies delist voluntarily from the stock market? Journal of Banking \& Finance, 37(12), 4850-4860. doi 10.1016/j.jbankfin.2013.08.022.

Rogers, P. (2006). Governança corporativa, mercado de capitais e crescimento econômico no Brasil. Dissertação de mestrado, Faculdade de Gestão e Negócios, Universidade Federal de Uberlândia, Uberlândia, MG, Brasil. Retirado de http://www.pablo.prof.ufu.br/artigos/dissrogers.pdf.

Saito, R., \& Padilha, M. T. C. (2015). Por que as empresas fecham o capital no Brasil? Revista Brasileira de Finanças, 13(2), 200-250.

Santos, I.T. (2010).Gerenciamentoderesultadosemfechamentodecapital. Dissertação de mestrado, Escola de Administração de Empresas de São Paulo, Fundação Getulio Vargas, São Paulo, SP, Brasil. Recuperado de http://www.anbima. com.br/data/files/A9/04/DF/00/EFD3A5104FEB5B9568A80AC2/ Disserta_o\%20-\%20Isabela\%20Travaglia\%20Santos\%20-\%20Vers_o\%20 CAPES\%20.pdf.

Santos, M. A. (2016). Internacionalização de Empresas e o Fechamento do Capital: Um estudo sobre a deslistagem no mercado brasileiro. 2016. Dissertação de mestrado, Faculdade de Gestão e Negócios, Universidade Federal de Uberlândia, Uberlândia, MG, Brasil.

Silva, A. L. C., \& Leal, R. P. C. (2006). Ownership, control, valuation and performance of Brazilian corporations. Corporate Ownership and Control, 4(1), p. 300-308.

Silveira, A. D. M., \& Barros, L. A. B. C. (2013). Determinantes da qualidade da governança corporativa das companhias abertas brasileiras. Revista Eletrônica de Administração, 14(3), 512-540.

Souza, J. A. S., Costa, W. B., Almeida, J. E. F., \& Bortolon, P. M. (2013). Determinantes e consequências do fechamento de capital nas práticas de gerenciamento de resultados. Revista Evidenciação Contábil \& Finanças, 1(1), 38-57. doi 10.18405/RECFIN20130103. 


\section{ABOUT THE AUTHORS}

\section{KLEVERSON DÁLITON SILVA MOREIRA}

Master's degree student from the Department of Business Administration, Universidade Federal de Uberlândia (UFU).

Avenida Mato Grosso, 3370, Umuarama - Uberlândia - MG - Brasil - CEP 38405-314

E-mail: kleversondaliton@hotmail.com

\section{JULIANA RODRIGUES OLIVEIRA}

Master's degree student from the Department of Business Administration, Universidade Federal de Uberlândia (UFU).

Av. João Naves de Ávila, 2121, Santa Mônica, Uberlândia - MG - Brasil - CEP 38408-100

E-mail: jujuro19@yahoo.com.br

\section{FERNANDA MACIEL PEIXOTO}

$\mathrm{PhD}$ in Administration from the Department of Business Administration, Universidade Federal de Minas Gerais (UFMG).

Associate Professor at the Department of Business Administration, Universidade Federal de Uberlândia (UFU).

Av. João Naves de Ávila, 2121, Santa Mônica, Uberlândia - MG - Brasil - CEP 38408-100

E-mail: fmacielpeixoto@gmail.com

\section{VINÍCIUS SILVA PEREIRA}

$\mathrm{PhD}$ in Finance from the Department of Business Administration, Fundação Getúlio Vargas (FGV).

Associate Professor at the Department of Business Administration, Universidade Federal de Uberlândia (UFU).

Av. João Naves de Ávila, 2121, Santa Mônica, Uberlândia - MG - Brasil - CEP 38408-100

E-mail: viniciuss56@ufu.br 